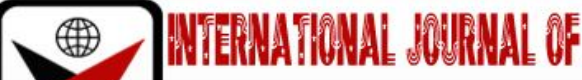

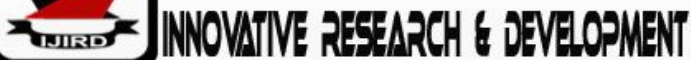

ISSN 2278 - 0211 (Online)

\section{The Prospects of Jewellery Works: The Case of Wa Municipality, Ghana}

\author{
Dr. Nicholas A. Tetteh \\ Senior Lecturer, School of Applied Art, Design \& General Studies, Wa Polytechnic, Ghana \\ Dr. Joe Adu-Agyem \\ Senior Lecturer, Department Of General Art Studies, KNUST, Kumasi, Ghana \\ Dr. Nana A. P. Arthur \\ Lecturer, Department Of General Art Studies, KNUST, Kumasi, Ghana
}

\begin{abstract}
:
Jewellery fabrication as a profession and a way of living has a socio-cultural and psychological influence in our society. It is characterized by various functional and symbolic art forms that have several ingenious techniques, skills and cultural facets undertone. Although there has been different type of Jewellery products used by the people of Wa municipality, little or no attention has been given to its viability as a means of income for those interested in its products and the sale of it. The study therefore, through the use of descriptive survey research methods ascertained the types of Jewellery works used, the frequency of their purchase and the philosophy of its use. It also unfolded some precious metals that can support the production of Jewellery in the Municipality. The population for the study comprised users of Jewellery works and mineral experts. Stratified and purposive sampling techniques were used. Primary data for the study were sampled from Jewellery consumers and precious metal dealers from the three zones in the municipality. Secondary data sources were gathered from books, journals, magazines and many others. Data gathered were assembled, analyzed and interpreted. It was found out that ten different types of Jewellery works are used in the municipality. It was discovered that $47.62 \%$ of the population of study buy Jewellery works each year. The study also unveiled the use of scrap metal made up of precious metal and pure gold as the fundamental source of material to produce Jewellery work in the Municipality. It was recommended that total attention for the potential of human resource for the Jewellery industry be given extreme support. Furthermore, the study underscored the potential of small-scale business set-up in Jewellery as a means of employment.
\end{abstract}

Keywords: Metal, jewelry, ferrous metal, non-ferrous metal

\section{Background to the Study}

Wa Municipality is one of the eleven Municipal Assemblies that constitutes the Upper West Region of Ghana as shown in Figure 1. The Municipality is divided into three zones and 14 operational areas as seen in Table 1.

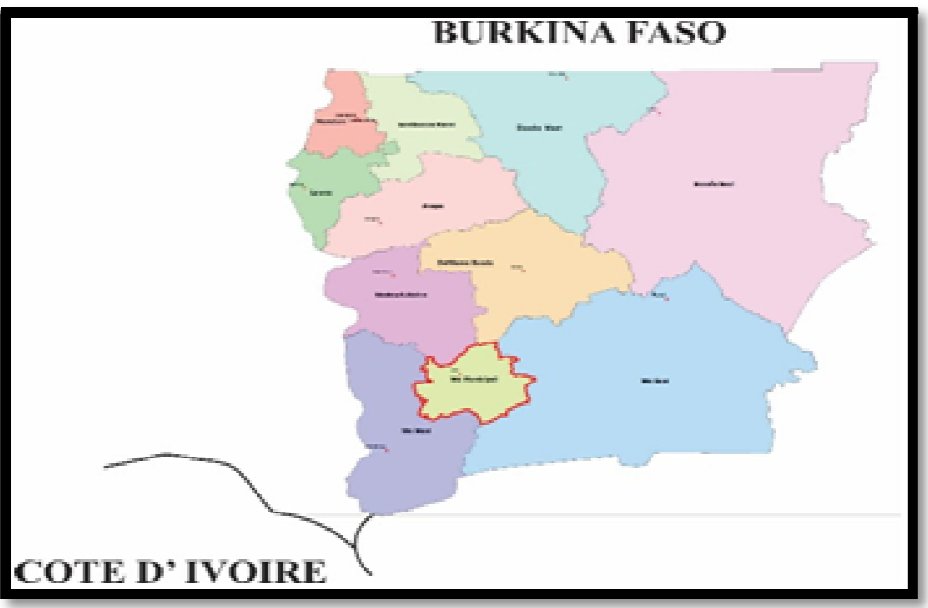

Figure 1: Location of Wa Municipality on Map Of

Upper West Region

Source: Lands Commission-Wa Municipal (2017) 


\begin{tabular}{|c|c|c|}
\hline Busa Zone & Bamahu Zone & Wa Central Zone \\
\hline Busa, Tabiasi, Pirisi, & Bamahu, Sing, Boli, & Charia, Nakore, Chansa, \\
Yibile, Sako, Kampaha. & Kpongu. & Valempele. \\
\hline
\end{tabular}

Table 1: Municipal Division and Operational Areas

Jewellery plays tactical, strategic and distinctive role encompassing functional imperatives. They are essentially embedded in a wide-range of social needs (Holl, 2000). In the region, one of the crafts and manufacturing industry accounted for by the 2010 census included metal design and fabrication. But in Wa Municipality, Jewellery works has now become one major end product which is inevitable in everyday life activity (Metropolitan Museum of Art, 2005).

\section{Statement of the Problem}

There are many functions that jewellery works perform for the people in Wa Municipality. They use it for marriage, body adornment, cloth decoration, religious purposes, wealth, inheritance and room or office decoration. Again, in respect to beauty, aesthetics and appreciation, jewellery works are undoubtedly used (Tettey, 2012). This has made jewellery works an integral part of the Ghanaian way of living particularly among the people of Wa municipality in the Upper West Region. With the availability of precious metal like gold in the region and the supply of silver, copper, brass and aluminum from the southern part of the country, it is challenging to appreciate why there is none of the metal design and fabricators producing jewellery works in the municipality yet the people use Jewellery works every day. Also, with the presence of metal design and fabricators who have been producing other metal works with high aesthetic values, it becomes difficult for one to understand why Wa Municipality cannot boast of any jewellery production and maintenance shop. Considering the availability of materials and the human resource with a certain level of skills in metal design and fabrication as well as the value that people in the municipality have for jewellery works, it is absolutely imperative that this vacuum cannot be left unbridged hence the need for this research.

Metalwork embraces a wide area of profession; some of which include blacksmithing, goldsmithing, silversmithing, casting, welding, jewellery fabrication and many others (Holl, 2000). All these professions come along with their working processes called metalworking. Metalworking is the process of using metals to fabricate and create functional items called metalworks. The term covers a wide range of metalworks from large items to precisely small and delicate jewellery work (Tetteh \& Adu-Agyem, 2014). Labi and Ansah (2008) stated exclusively the numerous metalworks that Ghanaians have been producing since colonial era. Typical among the metalworks are blacksmithing, filigree, jewellery fabrication; - goldsmithing, silversmithing and brass-smithing. The philosophy of these works is based on the cultural orientation of the Ghanaian people and this is centered on the culture of farming, hospitality, shelter and the value of beauty.

\subsection{Jewellery Works}

Holland (1999) describes jewellery as a personal ornament such as necklaces, rings or bracelets made from jewels, precious and non-precious metals and other substances.

Jewellery work is one of the types of metal works known in Ghana. Accordingly, since the study focal point is on jewellery work, knowledge must be advanced on what is jewellery work and how it does fit into this study. Advancing the discussion on jewellery work, Neumann (1982) postulates that the essential increase and the use of jewellery in the past few decades restate a truth that is many thousands of years old: man and woman needs personal adornment. This beautification in present terms is not only limited to the body but also homes, offices, vehicles, worship centres and many more. This spells out how relevant jewellery and metal works have become in our society making this study vital in our current dispensation for both economic and social necessity for the people of Wa Municipality and Ghana as a whole. Jewellery works cut across all society and is unique to the lifestyle of each society in the world (Untracht, 1985). Alluding to Untracht's statement means that the people of Wa municipality are living other society's lifestyle since they are not producing their own jewellery work. This in fact is problematic to the culture of the people of Wa municipality, in that they have been living in other society's culture in terms of jewellery usage. In Labi and Ansah (2008), account blacksmithing originated from the Northern, Upper East and Upper West regions. Some of the works produced to them included decorated bracelets, anklets, beads, rings and other objects in metal. In this direction, one may then ask why is Wa municipality and its people lacking in their own jewellery production units and are rather depending on import jewellery; as such the need for this study.

\subsection{Types of Jewellery}

There are different types of jewellery used across the globe which serves both primary and secondary purposes. The primary function of jewellery is to decorate and adorn while the secondary is to award. However, demand for different types of jewellery according to Maryon (1971) is basically influenced by various factors including its varieties, properties and buyer's preferences.

Kennett (2013) propounds five categories of jewellery. He labels them earrings, rings, bracelets, necklaces and brooches. Expatiating on Kennett's argument, if the categories could be identified with the parts of the body the jewellery is used, definitely there should be many categories philosophically. In this contemporary world, individuals use jewellery on many parts of their bodies such as the forehead, eyelid, nose, tongue, nipple, navel, penis, clitoris, toes and so on. Jewellery.com in supporting this argument, listed hair ornament, Neck, Arms, Hands, Body and Legs and feet as types of jewellery. 
Julee (2002) on the other hand opines that, so far as the consumer wishes to use the jewellery at a desired part of the body philosophically it forms part of the categories. This argument underscores the fact that there are no limited categories of jewellery types. This in effect is good news for jewelers since varieties of jewellery will be needed on the market making the jeweler always in business.

\subsection{Uses of Jewellery}

Jewellery has numerous functions. Human beings across cultures, geographies and social strata have always been attracted towards the use of jewellery. Emphasizing these statements, Maryon (1971) stressed most of these cultures have at some point in time had a practice of keeping large amounts of wealth stored in form of jewellery. Jewelleries have been used as trade goods by our forefathers many centuries ago. Jewelleries have been in use since ages for both its aesthetic as well as investment purposes.

Wearing jewelry may be deliberated an embroidery of everyday life according to Ahde-Deal (2013). Jewelry carries qualities, both external and internal, demanding them to be preserved. In her argument the only reason for women using jewellery is for social motives.

Be it as it may, Ahde-Deal's explanation is valid. Whether conscious or unconscious there are societal factors that influence people wearing jewellery in Wa municipality, Ghana, Africa and across the globe. These factors were certainly traced in the data of this study to give philosophical pedestal of jewellery usage in Wa municipality.

\subsection{Philosophy of Jewellery}

Jewellery as an ornament is symbolic and representational. These factors are influenced by what Eze (1998) describes as reflecting on human experience in search of answers to some fundamental questions. Jewellery is used by living and non-living things. Especially about living things human beings and animals are found the most users of jewellery. But as intellectual mid-wife, Socrates once said where there are humans, philosophy exist and where there is philosophy, humans cannot be separated from it. This philosophical state invariably originated the philosophical connotation of the use of Jewellery (Edusei, 1991).

Solomon and Higgins (2010) in helping to understand the word philosophy assert that philosophy is all about our experience in beliefs and attitudes about us and the world. Certainly so, according to Ahde-Deal (2013) there are beliefs, customs, rituals and attitudes in our society that underpin the philosophical theories of jewellery usage across the globe. The following are some of the underlying theories that gave impetus to philosophical use of jewellery in Wa municipality, Ghana and the world.

\subsubsection{Jewellery as Self-Expression}

Simmel (1986) a jewellery activist once noted, jewelry has philosophical orientations which are self-expressive. According to Ahde-Deal (2013) jewellery can be worn to give pleasure to and excite other people as well as to express the social class one belongs to. Works of jewellery at this current age are usually items of fashion. Simmel's view is of great concern to this study and had some validity in the data of this study.

In Ahde-Deal's study, the female in particular acquired and wore jewellery for the sake of fashion. These preferred jewellery works by females were more of outfit jewellery and are often bought to project a specific style or outfit. But obviously in Wa municipality and Ghana jewellery is used by women of course for fashion and many others with the men not excluded. The contemporary jewellery was often kept even though their time to be worn had been short. They also carried reminiscences from the times worn, but did not often carry expressive memories for a long time.

\subsubsection{Jewellery beyond Self-Expression}

Aside the tangible discussion of jewellery works that expresses the fashion aspects of it, there are other areas and one of them is the intangible. A section of jewellery users depend on jewellery works for its intangible features, like memories, identity, stories and beliefs regarding individuals, family members and heroes or heroines. Some of these features are the thematic principal areas for jewellery that goes beyond self-expression. Some male and female jewellery consumers often cherish intangible features of their jewellery as such the need to purchase them for use. Most often, the intangible features were the most important motives some people possess jewellery and the reason why they wear it on certain days (Ahde-Deal, 2013). Nonetheless, most jewellery are acquired and worn to convey remembrances and to establish intermediaries of previous circumstances and generations. This subtopic of the research is more about the out of sight side, the side acknowledged singularly by the wearer of the jewellery.

Durkheim's (1980) notion about jewellery as emblematic matters was also about the invisible and intangible side of jewellery in the 1980's. So, whereas Simmel (1986) sees jewellery as an attempt to please others, the interest of the researchers was about jewellery as subjectively meaningful objects with meanings secondary to adornment.

\subsection{Factors That Influence Jewellery Materials}

Artistically and creatively as it is, jewellery has innumerable materials usable in fabricating it. From the indigenous to contemporary jewellery as emphasized by Oliver (1966) and Dierks (1994), jewellery materials are not far fetch from our environment. They admitted that both precious and non-precious materials; so far as they are treated stand the test of time for jewellery production.

This assertion did not end there. In recent times Ahde-Deal (2013) and Summatavet (2005) identified silver, gold, copper, brass, aluminum, precious stones, seeds, wood, shell of animals, beads, stones, plastics and processed natural and artificial objects as the utmost resourceful materials that most men and women crave for to be used in fabricating their 
jewellery works. Kennett (2013) listed paper, fibre, wire, polymer clay, repurposed and recycled objects as some of the materials that can be used in fashioning jewellery works. Many philosophers believe that materials for making jewellery are enormous and should have no limit. This argument is conditional, irrespective of the wide range of objects available for the jeweller to use for making jewellery. There is one philosophical element opined by Oliver (1966) and Dierks (1994); the word, treat. Authoritatively if the objects are not treated and put into specification there is no material available for the jeweler (Tetteh, 2017).

\section{Objectives of the Study}

The fundamental objective of this study is to:

Assess the market prospects of Jewellery products and available precious metal in Wa municipality.

\section{Methodology}

Descriptive Survey research also known as normative survey research is a quantitative research in which the researcher collects data about one or more group of people to ascertain trends in their thinking, feeling, attributes, features, attitudes, opinions, behaviours and experience (Leedy \& Ormrod, 2005). The descriptive survey method looks accurately at the data and describes precisely what it sees. The study therefore is driven in the descriptive survey design. Cross-sectional survey is used to gather facts and figures from a sample that has been drawn from a pre-determined population at just one point in time even though the time taken to collect the data may be different from a day to a few weeks or more. Longitudinal survey assembles facts and figures on the same individuals at different points in time in order to study changes over time (Sanders, Lewis \& Thornhill, 2007). This research combines the two types of descriptive survey research to collect data in respect of the function of the research method.

The data collected included both statistical data as well as manuscript information so that the final database embodies quantitative and qualitative information.

Target population for the study of which the researchers generalised were persons who either fabricate or use metalworks as well as mineral experts in Upper West Region. The specified total group of persons from which a sample was actually selected were users of metalworks, minerals commission and galamsey operators in Wa municipality. These persons were the accessible population which became the study population. It was from this population that a practicable size, the research sample was selected. Since the population for the study was made up of different categories of people, the stratified random sampling was used for one category of the strata (users of metalworks) with the other (minerals commission and galamsey operators) being purposive sampling.

In order to generalise the findings of the objective of the study, questionnaire was stratified and distributed to 700 respondents who use jewellery. Out of the 700 jewellery users, the researchers were able to retrieve 672 of the questionnaires for analysis. Three broad categories of people constituted the strata sample size. The Christian fraternity; Catholic (100 respondents out of which 95 were retrieved) and Pentecost (100 respondents of which 97 were collected) all from the Busa zone, Islamic fraternity (300 respondents out of which 292 were retrieved) all from Wa central zone and the tertiary students; Wa Polytechnic students (100 respondents of which all were retrieved) and University of Development Studies-Wa campus students (100 respondents out of which 88 were retrieved) all from Bamahu zone. These categories of respondents were selected due to the discovery made from the jewellery consumers or users. The use of jewellery works come to play during religious and group gathering functions.

Five mineral experts were interviewed. It came to fore that there is gold deposit almost everywhere in Upper West Region and Ghana as a whole but for reasons of economic viability mining is only happening in some few defined areas. Places such as Enbopie, Dayonpra, Duoo, Moree, Duu, Jamposi, Kataa, Chrikpong, Maluwe, Pole and Jamposi at WaWest, along the Black Volta there are deposit of gold as given by the interviewees. Telephone interviews were also occasionally used as follow up to clarify information provided. All responses were retrieved from all the five respondents concerning the availability of mineral or precious metal in Wa municipality. See Table 2.for the general overview of categories of population and sample size.

The data gathered from the interviews, observations, and questionnaires have been organized based on the objective set for the study.

\begin{tabular}{|c|c|c|c|}
\hline Objective & Respondents & No of Respondents used & \% \\
\hline 1 & - Jewellery consumers & 100 & \\
& Members of Church of Pentecost (Busa zone) & 100 & 14.2 \\
& Members of Roman Catholic (Busa zone) & 300 & 14.2 \\
& Members of the Municipal Mosque (Wa central zone) & 100 & 42.5 \\
& Students Wa Poly Accountancy Department (Bamahu zone) & 100 & 14.2 \\
& Students UDS-Wa Business Department (Bamahu zone) & 700 & 14.2 \\
& - Mineral experts & 3 & 99.3 \\
& $-\quad$ Minerals Commissions & 2 & 0.4 \\
& & 5 & 0.3 \\
\hline & $-\quad$ Galamsey & 705 & 0.7 \\
\hline
\end{tabular}

Table 2: General Overview of Categories of Population and Sample Size 


\section{Presentations and Discussion of Findings}

\subsection{Jewelleries in Use in Wa Municipality}

Dominant among the metalworks used in Wa municipality but not produced is jewellery. All the three zones in the municipality make good use of jewellery by both the male and female. Finger ring, earring, necklace and pendant, bracelet and hair jewellery were the identified jewellery works used but not produced in the municipality.

\subsection{Selected Finger Rings Used in Wa Municipality}

There are different types of jewellery works used in Wa municipality by both male and female. One of such is finger ring. Different types of finger rings have been captured by the study for discussion.

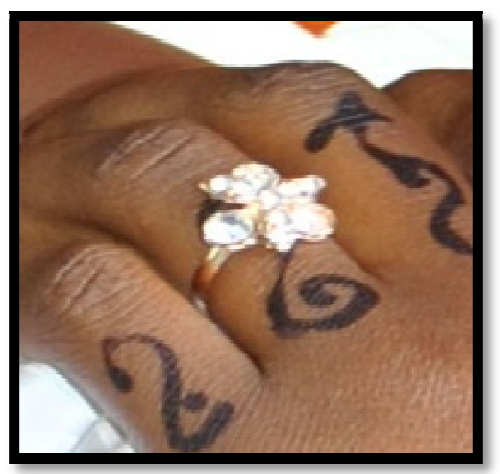

Figure 2: Finger Ring (A)

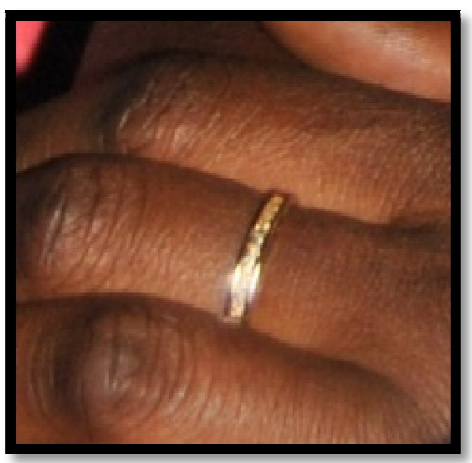

Figure 3: Finger Ring (b)

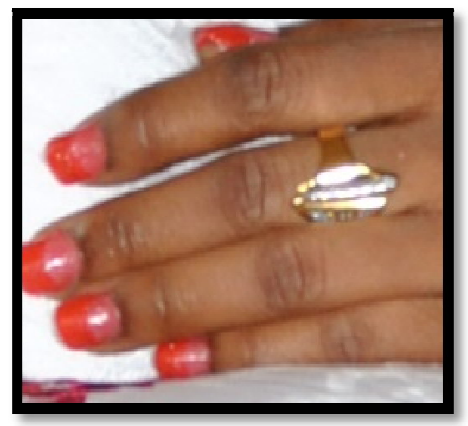

Figure 4: Finger Ring $(C)$

All the finger rings displayed from Plates 1 to 3 are finger ring of females in Wa municipality. Interaction by the researchers with the wearers confirmed and underscored the argument that jewellery used in the municipality are imported elsewhere to the region. The users of these rings noted that they fancy aesthetically beautiful finger rings as such they use them more often. They buy them from Wa market, Kumasi, Kintampo, Tamale, Burkina Faso and Accra. Observation made of the finger rings indicates that the people appreciate finger rings with either texture or designs in and around the ring to create emphasis. The kind of metal for finger rings preferred by the people: are gold, silver and copper. According to Madam F. Suleman (personal communication, January 12, 2016) she uses the jewellery to add to her beauty. Without the jewellery on the finger and on the body, she feels incomplete.

\subsection{Selected Earrings Used in Wa Municipality}

The earrings in our Ghanaian culture are meant for the female to identify their feminism and to distinguish them from the male counterpart in the society. This culture implication is no different in Wa municipality when it comes to the use of earring. Females from the babies stage through to adults in Wa use earrings. There are different types of earrings though. Some sophisticated and other simple or less complicated in design. All the two identified are very well used by the 
females. Taste for earrings can be determined by the preferred choice of the user. The discoveries in this study indicated that the women's taste for earrings are those flamboyant, big and self-expressive ones full of aesthetic qualities and or intricate designs but simple technically. Plates 4 to 6 give pictorial detail of the survey.

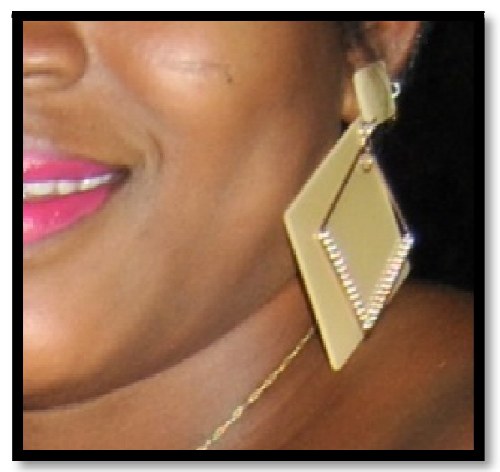

Figure 5: Earring (A)

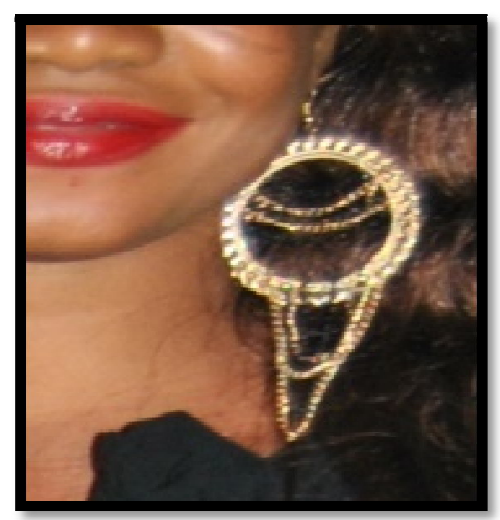

Figure 6: Earring (B)

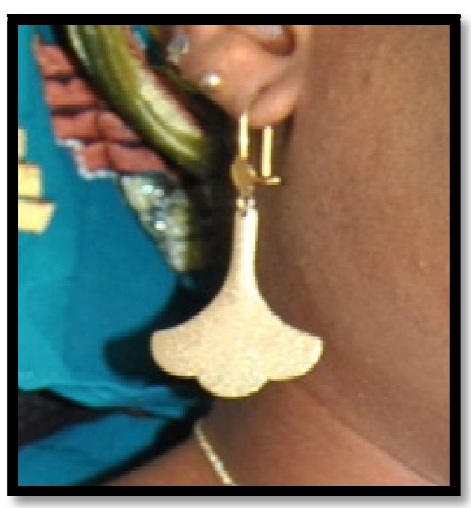

Figure 7: Earring (c)

\subsection{Selected Necklace and Pendants Used in Wa Municipality}

The survey also uncovered necklace and pendants as one of the choices of jewellery products the people in the municipality make good use of. The use of necklace and pendants is associated to the career women and women going for functions such as church, party, school and date outing. These noted points influenced the way in which these photographs were taken. A focus group interview with five of the women espoused that they started using these jewellery works for more than two decades now. Dressing without their jewelleries psychologically makes them feel inferior to their colleagues who are dressed in it. According to them, their best time in jewellery is when they are going to parties, dateouting, festivals, durbar, group and religious gathering. See plates 7-9.

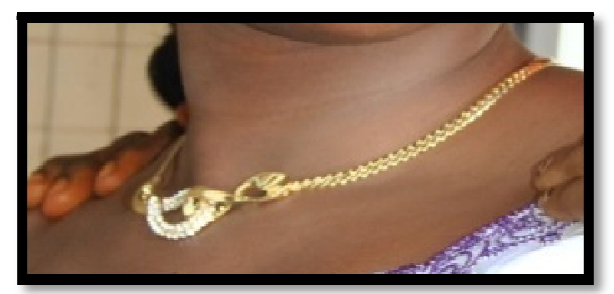

Figure 8: Necklace (a) 


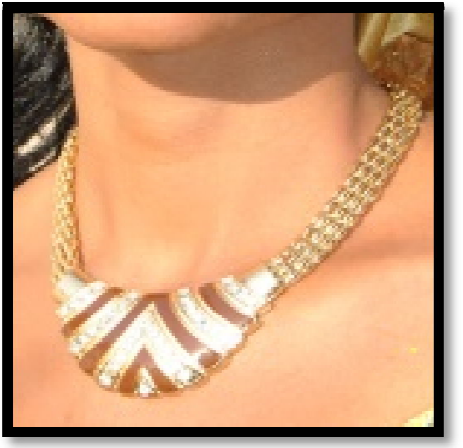

Figure 9: Necklace (b)

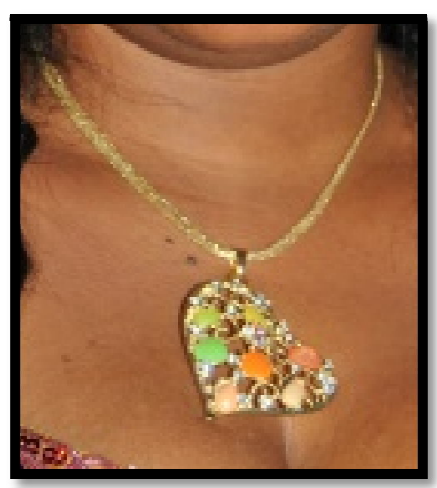

Figure 10: Necklace (c)

5.5. Selected Bracelets and Bangles Used in Wa Municipality

The municipality can make reference to bracelets and bangles being used by the people although not produced by them. The choice of quality design and good finished work is as usual the preferred one by the people. See Plates 9-12. Gold, silver, aluminum, bronze and other forms of metal are the selected few choices of metal that the people patronized when buying their jewellery works.

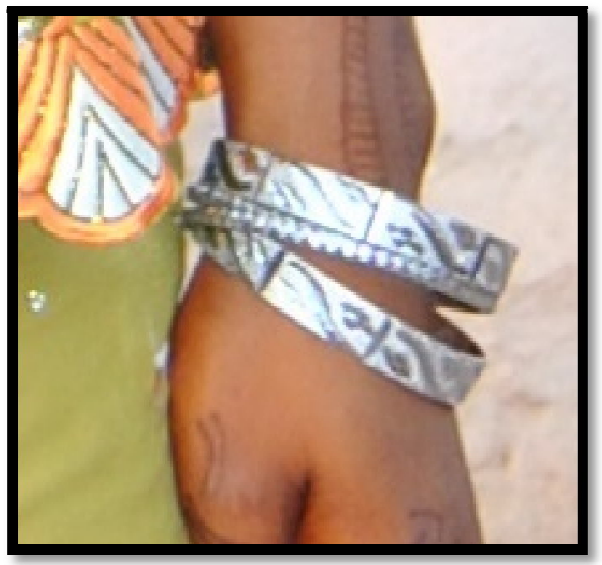

Figure 11: Bracelet (a)

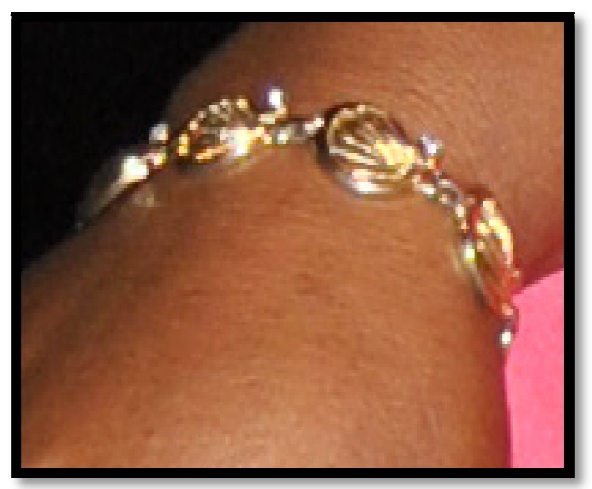

Figure 12: Bracelet (b) 


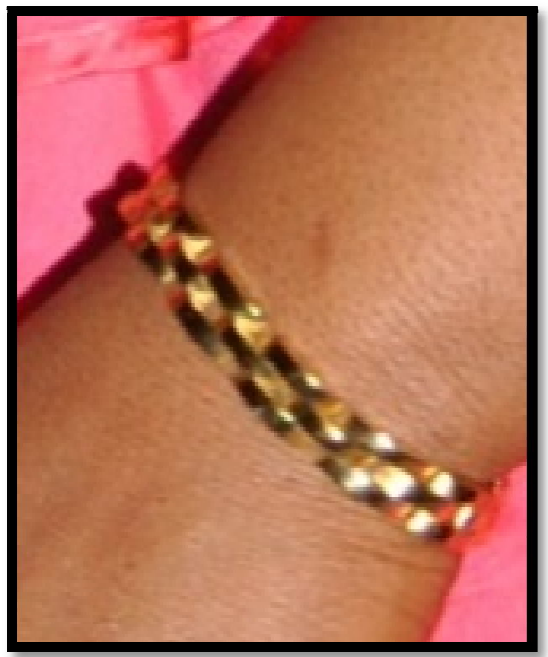

Figure 13: Bracelet (c)

\subsection{Selected Hair Jewellery Used in Wa Municipality}

Hair jewellery was also identified to be used by the women especially on ceremonial occasions. Hair jewellery is not frequently used in the municipality. The most people who use it are the Muslims during marriage occasions and naming ceremonies. See Plates 13-14.

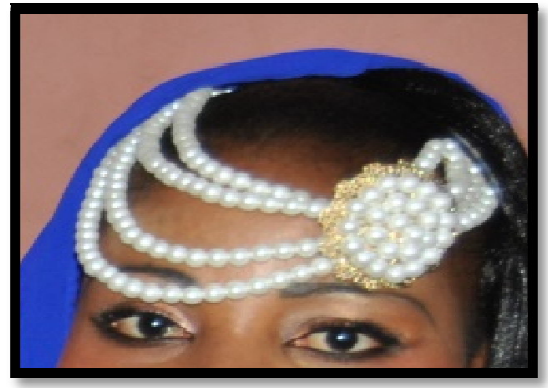

Figure 14: Hair jewellery (a)

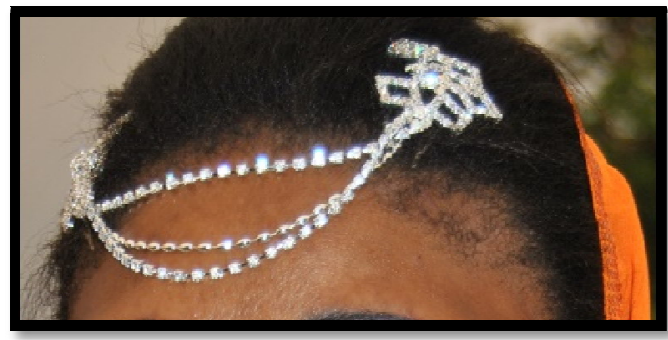

Figure 15: Hair Jewellery (B)

\subsection{Selected Anklets Used in Wa Municipality}

Anklet was unfolded as one of the jewellery patronised and used by the people in the municipality. It is not common among the indigenes but popular with the other ethnic groups who are living in the municipality. See Plates 1516.

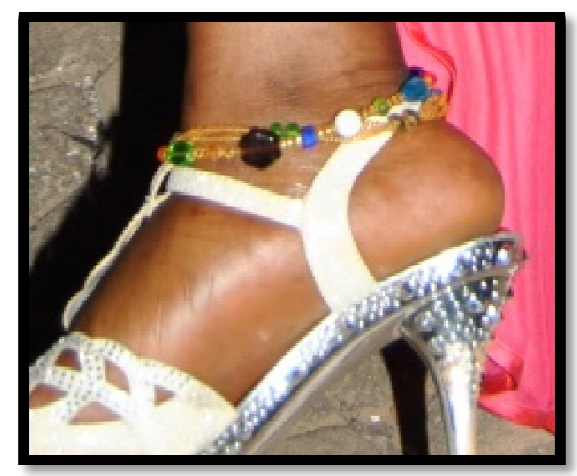

Figure 16: Anklet (a) 


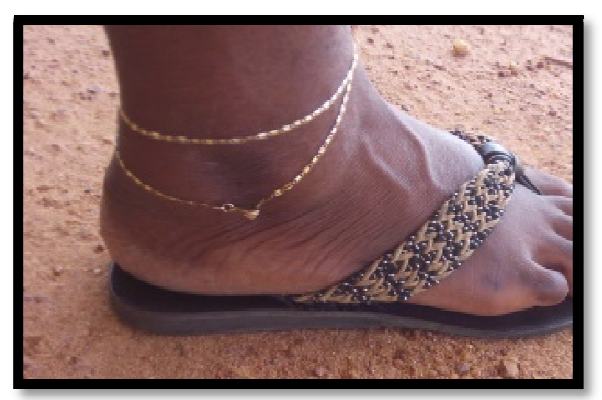

Figure 17: Anklet (b)

It must be stated that the respondents for the use of jewellery in the municipality could not tell and describe the technical details as to how the works they are using were produced.

\subsection{Philosophical Significance of Jewellery Works Used in Wa Municipality}

Eze (1998) expatiated philosophy to cover shelter, existence, occupation and body adornment. This philosophy underscores the categories of metalworks used or found in Wa municipality. The researchers delved into the significance of the Jewellery works people are using in Wa municipality.

Body adornment is peculiar to mankind. All over the world, men and women decorate their bodies. This acceptable way of living is no different in Wa municipality. The people in Wa municipality use jewellery for many reasons. In view of these reasons all the types of metals are used in producing jewellery. The most people that make maximum use of jewellery in Wa are women. In view of that the dominant metal is the non-ferrous metal also known as precious metal. These metals are soft and easy to manipulate. It is the feminine metal as compared to the ferrous metal. The non-ferrous metal jewelleries are used for body adornment purposes while the ferrous metals are used for medicinal or spiritual protection purposes. The non-ferrous metals used in jewellery works used in Wa are gold, silver, copper, brass and aluminum. The gold and silver are not used in producing the entire jewellery works but rather are used to plait the works. On the other hand, those jewellery works made in ferrous metal are left in the ferrous metal state.

Because the works are used on the body, precious metals are used. Philosophically the metals used are earthly defined and naturally discovered metals. Jewellery is for women and so care must be taken when producing it. The purpose of the jewellery work determines the design and the type of metal to use. The jewellery works used in the municipality serves as; identity, protection, healing, livelihood (black power) and worship. It was recognized that the Metalworks for adornment: Jewellery used in the municipality are not produced there.

\subsection{Assessing the Market Prospects of Jewellery Products and Available Precious Metal in Wa Municipality}

The objective presents the findings and discussion of data obtained through questionnaire, interviews and observations on the market prospects of Jewellery works in Wa municipality, the types of jewellery work used in Wa municipality, and the available precious metal in the municipality. The information obtained were transcribed and analyzed into frequencies and percentages using excel. This was to make their interpretation stress-free for analyses. For the purpose of effective comprehension and subsequent easy interpretation, the data were put into tables, figures and plates.

\subsubsection{Background Information of the Respondents}

A total number of 672 respondents were accessed out of which 292 representing $43.45 \%$ were male and 380 being female representing $56.55 \%$. The female representation dominated this part of the research; underscoring the theory in this study that women make use of jewellery more than the male counterpart. The total male representation in the study was 292 representing $43.45 \%$ of the total population. The age range among the male representation were 29 below 20, 150 for 21-30, 56 for 31-40, 34 for $41-50$ and 23 for above 50. These figures represented 9.93\%, 51.37\%, $19.18 \%, 11.64 \%$ and $7.88 \%$ respectively. It was found out that the youth were the majority of people that made enormous use of jewellery. This revelation is a golden opportunity for the jewellery industry in Wa municipality. Its implication includes profit maximization, exploration of the natural gold, scrape aluminum, brass and copper metal resource and human resources in Wa municipality.

In the jewellery industry women cannot be ignored since either way they have a role to play (Ahde-Deal, 2013 [27]). So, it was in this study. The female representation was the highest. The female respondents were 380 representing $56.55 \%$ of the total population. Age below 20 recorded 46 females, age between 21-30 recorded 144 females, age between 31-40 recorded 97 females, age between 41-50 recorded 58 females and age 50 and above recorded 35 females. Each of the age range recorded $12.11,37.89,25.53,15.26$ and 9.21 percentages respectively. The age group that dominated the study was 21-30. It constituted more than half of the respondents. The age group 21-30 represented $43.75 \%$ with a total of 294 respondents. Age group 31-40 made up 22.77\% of the total with 153 respondents. This was followed by $41-50$ age group with 92 respondents representing $13.69 \%$ of the total respondents. 75 respondents representing $11.16 \%$ of the population were below 20 years of age while $8.63 \%$ representing 58 of the respondents above 50 were accessed for insightful information for analysis. The age distribution of respondents gives enough reasons for jewellery production sustainability. Youth constituted the largest consumers of the jewellery works in use in the municipality and this discovery philosophically gave grounds for the prospects of jewellery industry in the region. 
5.10. Information on the Trend of Jewellery Work Consumption in Wa Municipality

\begin{tabular}{|c|c|c|c|c|c|c|}
\hline & \multicolumn{2}{|c|}{ Male } & \multicolumn{2}{c|}{ Female } & \multicolumn{2}{c|}{ Total } \\
\hline & Frequency & $\%$ & Frequency & $\%$ & Frequency & $\%$ \\
\hline Yes & 217 & 32.29 & 374 & 55.66 & 591 & 87.95 \\
\hline No & 75 & 11.16 & 6 & 0.89 & 81 & 12.05 \\
\hline Grand Total & 292 & 43.45 & 380 & 56.55 & 672 & 100 \\
\hline
\end{tabular}

Table 3: Do You Use Jewellery?

The Table 3 shows that the interest of female use of jewellery is higher than the male counterpart in Wa municipality. Majority of the female respondents said 'yes' to the use of jewellery and less number of them responded 'no' to the use of jewellery as compared to the male respondents. In this regard, jewellers who wish to take advantage of the market prospects must focus more on Jewellery made for female than that for male.

\begin{tabular}{|c|c|c|c|c|c|c|}
\hline & \multicolumn{2}{|c|}{ Male } & \multicolumn{2}{c|}{ Female } & \multicolumn{2}{c|}{ Total } \\
\hline & Frequency & $\%$ & Frequency & $\%$ & Frequency & $\%$ \\
\hline Once & 201 & 29.91 & 119 & 17.71 & 320 & 47.62 \\
\hline Twice & 47 & 6.99 & 163 & 24.26 & 210 & 31.25 \\
\hline Thrice & 5 & 0.74 & 51 & 7.59 & 56 & 8.33 \\
\hline Four & 0 & 0 & 15 & 2.23 & 15 & 2.23 \\
\hline Five or more & 5 & 0.74 & 22 & 3.28 & 27 & 4.02 \\
\hline None & 34 & 5.06 & 10 & 1.49 & 44 & 6.55 \\
\hline Grand Total & 292 & 43.44 & 380 & 56.56 & 672 & 100 \\
\hline
\end{tabular}

Table 4: How Many Times Do You Buy Jewellery for Your Personal Use or

For A Relative in a Year

The study underscored the frequent use of jewellery in Wa municipality with the information provided in Table 4The statistic shown in Table 6.2 indicates the rate at which people buy jewellery in Wa municipality. This gives assurance to any jewellery factory yet to be set-up in the municipal that it would not run at a loss. At least $47.62 \%$ of the population per the data is in the position to patronise the jewellery factory within a year for profit maximisation.

\begin{tabular}{|c|c|c|c|c|c|c|}
\hline & \multicolumn{2}{|c|}{ Male } & \multicolumn{2}{c|}{ Female } & \multicolumn{2}{c|}{ Total } \\
\hline & Frequency & $\%$ & Frequency & $\%$ & Frequency & $\%$ \\
\hline Gold & $158 / 258$ & 61.24 & $295 / 370$ & 79.73 & $453 / 628$ & 72.13 \\
\hline Silver & $219 / 258$ & 84.88 & $289 / 370$ & 78.11 & $508 / 628$ & 80.89 \\
\hline Copper & $160 / 258$ & 62.02 & $248 / 370$ & 67.03 & $408 / 628$ & 64.97 \\
\hline Brass & $106 / 258$ & 41.09 & $160 / 370$ & 43.24 & $266 / 628$ & 42.36 \\
\hline Aluminum & $66 / 258$ & 25.58 & $21 / 370$ & 5.68 & $87 / 628$ & 13.85 \\
\hline Other & $97 / 258$ & 37.59 & $80 / 370$ & 21.62 & $177 / 628$ & 28.19 \\
\hline
\end{tabular}

Table 5: What Type Of Metal Jewellery Do You Like?

Inferring from the data in Table 5. the most appropriate metals to use when one intends to establish jewellery in the municipality are gold, silver, copper, brass, aluminum and others. Interestingly most of these metals are available in and around the environment in the municipal. This information is welcoming to investors and industrialist.

\begin{tabular}{|c|c|c|c|c|c|c|}
\hline & \multicolumn{2}{|c|}{ Male } & \multicolumn{2}{c|}{ Female } & \multicolumn{2}{c|}{ Total } \\
\hline & Frequency & $\%$ & Frequency & $\%$ & Frequency & $\%$ \\
\hline Yes & 279 & 41.52 & 379 & 56.40 & 658 & 97.92 \\
\hline No & 13 & 1.93 & 1 & 0.15 & 14 & 2.08 \\
\hline Grand Total & 292 & 43.45 & 380 & 56.55 & 672 & 100 \\
\hline
\end{tabular}

Table 6: Would You Like Jewellery to be Produced In Wa?

On the basis of the wish of jewellery production in Wa municipality which this question suggested, it is clear in Table 6 that the people of Wa municipality are willing to have it established. They have also shown the interest of patronising jewellery products. This is resourceful enough to make jewellery a good venture in the municipality. 


\begin{tabular}{|c|c|c|c|c|c|c|}
\hline & \multicolumn{2}{|c|}{ Male } & \multicolumn{2}{c|}{ Female } & \multicolumn{2}{c|}{ Total } \\
\hline Types of Jew & Frequency & $\%$ & Frequency & $\%$ & Frequency & $\%$ \\
\hline Finger Ring & $217 / 258$ & 84.11 & $361 / 370$ & 97.57 & $578 / 628$ & 92.04 \\
\hline Earring & $11 / 258$ & 4.26 & $369 / 370$ & 99.73 & $380 / 628$ & 60.51 \\
\hline Necklace & $210 / 258$ & 81.39 & $305 / 370$ & 82.43 & $515 / 628$ & 82.01 \\
\hline Bracelet & $98 / 258$ & 37.98 & $258 / 370$ & 69.73 & $356 / 628$ & 56.69 \\
\hline Bangle & $86 / 258$ & 33.33 & $262 / 370$ & 70.81 & $348 / 628$ & 55.41 \\
\hline Anklet & $1 / 258$ & 0.39 & $193 / 370$ & 52.16 & $194 / 628$ & 30.89 \\
\hline Toe Ring & $0 / 258$ & 0.00 & $142 / 370$ & 38.38 & $142 / 628$ & 22.61 \\
\hline Tongue Ring & $0 / 258$ & 0.00 & $92 / 370$ & 24.86 & $92 / 628$ & 14.65 \\
\hline Tiara/Hair pin & $0 / 258$ & 0.00 & $233 / 370$ & 62.97 & $233 / 628$ & 37.10 \\
\hline Nose Ring & $0 / 258$ & 0.00 & $36 / 370$ & 9.73 & $36 / 628$ & 5.73 \\
\hline Others & $13 / 258$ & 5.04 & $33 / 370$ & 8.92 & $46 / 628$ & 7.32 \\
\hline None & $1 / 258$ & 0.39 & $0 / 370$ & 0.00 & $1 / 628$ & 0.16 \\
\hline
\end{tabular}

Table 7: Which Types of Jewellery Work Do You Like?

In the quest of finding the types of jewellery most patronised in the Wa municipality to aid in giving direction for prospective jewellery fabricators, the statistics in Table 6 explain the trend of jewellery choices in the municipality. From the study with the backdrop of Table 6 , it reveals that any form of jewellery fabrication respectfully should be tailored to body adornment jewellery works. Professionally and for maximisation of resources and profit, it is prudent for the study to look to the direction of the preferred choice of type of jewellery works patronized by the people in the municipality. This in effect will lead investors and industrialist to make an inform decision in the types of jewellery works to start production with.

\begin{tabular}{|c|c|c|c|c|c|c|}
\hline & \multicolumn{2}{|c|}{ Male } & \multicolumn{2}{c|}{ Female } & \multicolumn{2}{c|}{ Total } \\
\hline Reasons & Frequency & $\%$ & Frequency & $\%$ & Frequency & $\%$ \\
\hline Religion & $170 / 258$ & 65.89 & $195 / 370$ & 52.70 & $365 / 628$ & 58.12 \\
\hline Marriage & $195 / 258$ & 75.58 & $316 / 370$ & 85.41 & $511 / 628$ & 81.37 \\
\hline Beautification/ fashion & $233 / 258$ & 90.31 & $271 / 370$ & 73.24 & $504 / 628$ & 80.25 \\
\hline Feminism & $0 / 258$ & 0.00 & $319 / 370$ & 86.22 & $319 / 628$ & 50.79 \\
\hline Appreciate & $178 / 258$ & 68.99 & $291 / 370$ & 78.65 & $469 / 628$ & 74.68 \\
\hline Protection & $114 / 258$ & 44.19 & $123 / 370$ & 33.24 & $237 / 628$ & 37.74 \\
\hline Wealth & $80 / 258$ & 31.01 & $172 / 370$ & 46.49 & $252 / 628$ & 40.13 \\
\hline Others & $85 / 258$ & 32.95 & $164 / 370$ & 44.32 & $249 / 628$ & 39.65 \\
\hline \multicolumn{2}{|c|}{ Male } & \multicolumn{2}{|c|}{ Female } & \multicolumn{2}{c|}{ Total } \\
\hline Reasons not & $21 / 258$ & 8.14 & $21 / 370$ & 5.68 & $42 / 628$ & 6.69 \\
\hline Religion & $25 / 258$ & 9.69 & $3 / 370$ & 0.81 & $28 / 628$ & 4.46 \\
\hline Health & $26 / 258$ & 10.08 & $20 / 370$ & 5.41 & $46 / 628$ & 7.32 \\
\hline Others
\end{tabular}

Table 8: Any Reason(S) Why You Use Jewellery Work(S) or Not?

The people of Wa municipality were not using jewellery for jewellery sake. They had their reasons and beliefs associated to its use. The implication for the data in Table 8 tells that the people in Wa municipality use jewellery for identity, protection, fashion, healing, feminism, livelihood, "black power", beautification and worship. Inferably there will always be the need of any of these reasons at any time of the season. This data again is good for economic growth and jewellery business.

\subsection{Analyses on Interviews}

Unstructured interview was conducted to enable the researchers solicit first-hand information on availability of precious metal in the Wa municipality. The interviewees were categorised into two groups. The first group was the mineral experts which in this case was the Minerals Commission Department in Wa municipality. The second group was the galamsey operators. The free-flow of the interviews and the spontaneity with which questions were asked facilitated the provision of detailed information by interviewees. Telephone interviews were also occasionally used as follow up to clarify information provided.

\subsection{Mineral Experts}

Three mineral experts were interviewed. The director, deputy director and chief driver of minerals commission of the Upper West Division availed themselves for the interview. According to Mr, V. Amekor (Personal Communication, February 19, 2016), "there are gold deposit almost everywhere in Upper West Region and Ghana as a whole but for reasons of economic viability, mining is only happening in some few defined areas". It unfolded that there has not been any gold mineral discovery in Wa municipality. The reason is the total habitation and residential development of people in Wa municipality. The Wa municipal land has been totally occupied and as such there is no open place to test for gold availability. But the most important information worth noting is the fact that the nearby or immediate surroundings of the 
municipality are quite rich with precious minerals. This argument backs the researchers' beliefs that gold is present in Wa municipality but due to inhabitation of the land, much cannot be done. The interviewees with more than five years of working experience in their field revealed the availability of gold in the region.

According to Mr. D. Gyan (Personal Communication, February 23, 2016), "officially, Jonfia in Wa East district and Kuntse in the Nadowli districts are the district that gold is being mined officially in small scale quantity". Both Mr. Amekor and Mr. Gyan named a place called Azuma in the Wa West District which is the only place where gold is being mined on commercial bases. The three interviewees confirmed there is work on-going at Jirapa district, the Nandom district, Lawra district and the Wa west district for small-scale mining. The respondents also emphasized that their office does not take into account records of galamsey happenings in the region all though they liaise with them informally. Some of the galamsey mining places include: Enbopie, Dayonpra, Duoo, Moree, Jamposi at Wa-West, along the Black Volta there are deposit as given by the interviewees.

The researchers discovered that conditionally the lasting period for which gold mining can take place at each mining site is five years. They identified mining industrial equipment and tools by operators to play a significant role in how long a mining site may last. As to the quantity of gold mined in the region for use, the respondents explicitly said the commission branch in Wa cannot tell. Rather they pointed out to the galamsey operators and licensed gold buyers as those to be in the best position to answer that question. The respondents argued that they are not equipped to get that information.

The respondents underlined the fact that a jewellery production in Wa municipality would not compete with raw gold due to the availability of gold in the region from galamsey operators who for many years to come would still be operating. But they were quick to add that the price of gold in Wa would not be different from price of gold across the country since the miners and buyers communicate always to check the price on the global market.

\subsection{Galamsey Operators}

The quest to ascertain direct source of raw materials for potential jewellery fabricators in Wa municipality inspired the researcher to go on the galamsey field. The researchers interviewed two galamsey operators who belonged to the only well-known galamsey group called Jamaica Youth.

Bashiru Gambo and Alhassan Toufic were the two respondents who willingly provided primary data on the raw source of gold in the municipality. They confirmed there are more gold available in the region. For close to two decades they have been operating as galamseyers in the region. According to them currently they are operating in five mining sites. These include Duu, Kuntse, Chrikpong, Jamposi and Pole. The interviewees confirmed the five-year duration of the mining at each site but to them it is because they are not well equipped. They all agreed that with enough support of logistics they can mine for more than a decade at one particular site. More revealing, these galamsey operators said after abandoning the site for about a decade or more years they go back to them for gold.

The researchers ascertained that they determine the availability of gold at their mining sites through observation and the nature of mountainous or rocky site. The sparkling yellowish appearance of substance on any broken stone is an indication of the presence of gold (see Plates 17-19).

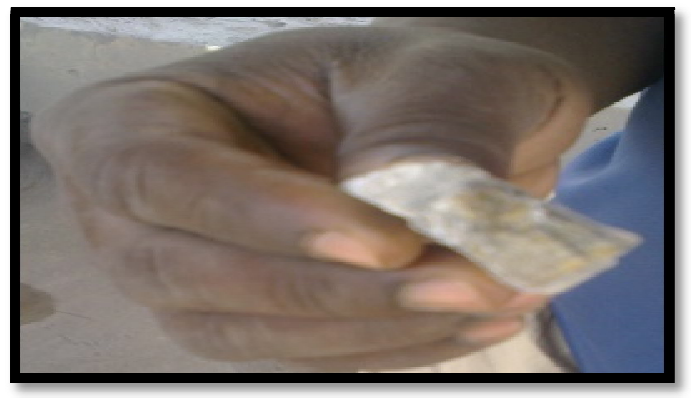

Figure 18: Gold Contain in an Ore

Source: Field Survey by the Researcher, 2016

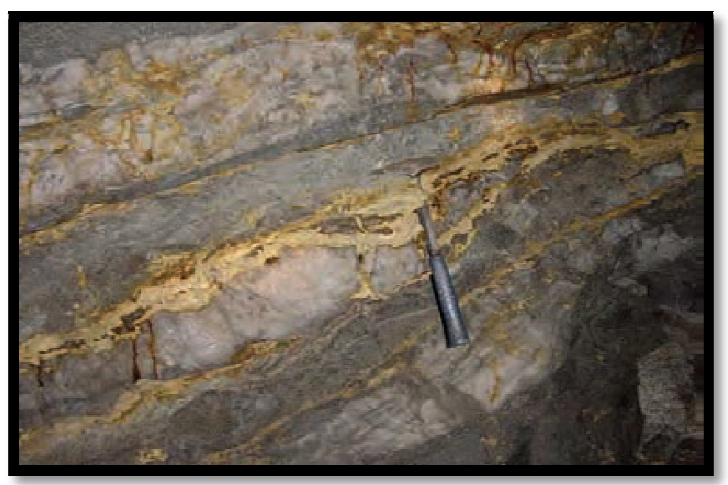

Figure 19: Evidence of gold in a mining rock Source: Precious minerals in everyday life (2012) 


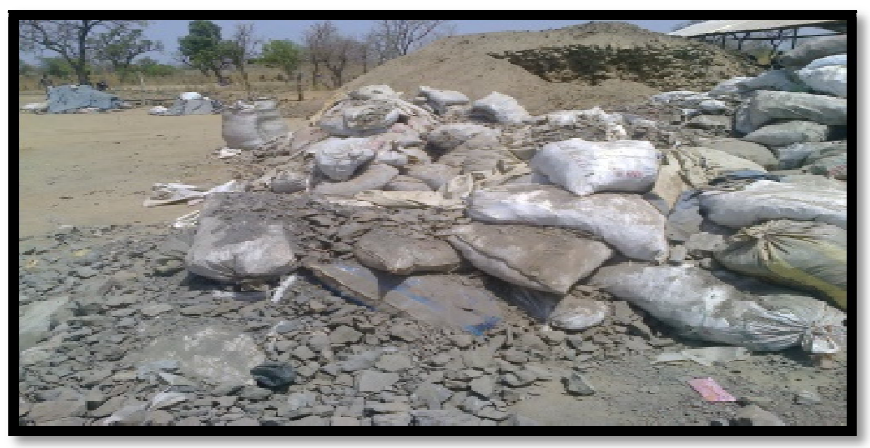

Figure 20: Ore measured in head load quantity at Cherie gold washing site in Wa Municipality.

Source: Field survey by the researcher, 2016

The research revealed that the minimum raw gold processed a day is 2 grams at their sites. The maximum could be five times the minimum. They sell their gold mostly in Wa to the gold buyers. Though they have links outside the region to which they sell gold to, they mostly deal with them on a large scale. They applauded jewellery fabrication shops or centers. They agreed to supply raw gold to the jewellery fabricators so far as they would come to them for the gold.

\section{Major Findings}

The in-depth study on the jewellery works used in Wa municipality and its prospect brought to fore the following major findings.

Although Jewellery was one of the most used metalwork in Wa municipality, there were no identified place or places in the municipal that jewellery was produced for sale or by customers' order. The study found out that brass and aluminum silver, gold, copper and others such as bronze, sterling silver, stainless steel metal, were the most metal preferred by the people to use in producing Jewellery.

The study discovered ten different types of Jewellery identified to be the scope of Jewellery works used by the people in Wa municipality. The ten were: Finger rings; used on the finger, Necklace; used on the neck, Earring; used on the ear, Bangle; used on the wrist, Bracelet; used on the wrist, Hair pin: used on the head, Anklet: used on the ankle, Toe ring: used on the toe, Tongue ring: used on the tongue and other forms of Jewellery including nipple ring, naval ring and nose ring. But out of the ten identified used Jewellery, finger ring, earring, bangle, bracelet, necklace and hair pin were the most patronised and most used Jewellery in the municipality. It was also discovered that $47.62 \%$ of the population of study buy Jewellery works each year. Aside available precious scrap metals such as copper, brass and aluminium, gold ore were present in Jonfia, Enbopie, Dayonpra, Duu, Kataa, Chrikpong, Maluwe, Pole, Moree, Jamposi, Kuntse and many other areas had been identified as additional material resources that can sustain Jewellery industry in Wa municipality.

\section{Conclusions}

The data collected for the study revealed that there is a huge market prospect for Jewellery products in the municipality. Regardless of their religion and gender the people of Wa municipality patronize Jewellery works made for different purposes. They prefer the native precious metals such as gold, silver, copper, brass and aluminum for their Jewellery products. Ironically, most of the Jewellery used in the municipality are purchased from outside the Region. The research identified ten different types of Jewellery works patronized by the people in Wa municipality. But the most patronized conforms to Kennett (2013) assertion of finger rings, necklace, earring, bangle and bracelet.

Metalworks for adornment was philosophically important to the people due to its: identity, protection, healing, livelihood (black power) and worship facets. It was also revealed that natural circumstance, societal values and norms, religion and the need to protect, philosophically underpinned the use of jewellery by the people of Wa municipality. The study also appreciated religion, health, and other factors as the bases for those who disliked the use of Jewellery in the municipality. The study established various locations around the municipality where gold mineral is present for economic purposes. Areas established for mining purposes by both the minerals commission and galamsey operators include Jonfia, Kuntse, Enbopie, Dayonpra, Duu, Kataa, Chrikpong, Maluwe, Pole, Moree, and Jamposi. According to the data collected mining site can last for more than a decade depending on the industrial machine available for the miners. The study revealed that the maximum gold extraction per day by the galamsey operators with their limited local tools and equipment amount to ten grams.

But almost all the gold mined in the region are sold out to agents in Kumasi, other parts of the country and most especially to the neighbouring countries like Burkina Faso and Cote D'Ivoire. The study shows that the lack of industries with interest of using gold as their raw materials has contributed to this phenomenon in the region. Addressing this challenge will demand industrial set-up of business; particularly small scale Jewellery industries in the region with the help of NGO's and government. In this current metal-fashion dispensation, the argument can be made about the basic principles used in fabricating any set of metalworks to be reflective in another set of metalworks. As such, whether or not the people do not produce Jewellery but are able to produce other forms of metalworks, means the technique they use can be transferred into jewellery production. 


\section{Recommendations}

Based on the findings and conclusions of the study, the following recommendations were made:

Due to the lucrative nature of the jewellery industry in our current dispensation of which the study has even buttressed on, non-interested members and even those who are not into the metal industry should be encouraged to develop the interest since technically it does not take much to become a jeweller and at the same time they can make a lot of money.

The needed attention and support should be given to selected few metal design and fabricators in the municipality to train them to start Jewellery production in the municipality.

Sandwich programmes should also be organised by Art Institutions and consultancy firms both within and outside the region for the people interested in entering the jewellery industry as well as other metal design fabricators. Since there is no jewellery centre in the region, the study recommends a set-up of Jewellery industry with immediate effect.

Tools and materials sale shop should be set up immediately particularly for individuals who are interested in setting up jewellery fabrication workshops in the municipality.

Efforts should be intensified to make the mineral operators in the region cooperate with the metal industry in the region in order to give any jewellery centre the needed material resource rather than exporting them to the south of the country and outside the country.

The minerals commission in the Wa municipality must device a means to quantify the minerals mined by the industrial miners, small scale miners and galamsey operators in order to be able to provide all the necessary information needed on quantity of gold mined in the region be it quarterly or yearly.

Non-ferrous scrap metals such as brass, copper, aluminium should be made useful in the production of jewellery works for the people to use.

\section{References}

i. Ahde-Deal, P. (2013). Women and Jewelry: A Social Approach to Wearing and Possessing Jewelry. Helsinki, Finland: Unigrafia Publication. p. 27.

ii. Dierks, L. (1994). Creative Clay Jewelry, extraordinary, colourful, fun designs to make from polymer day. New York, USA: Altamout Press. p. 5

iii. Durkheim, É (1980). Uskontoelämän alkeismuodot: Australialainen toteemijärjestelmä. (Original French edition Les formes élémentaires de la vie religieuse, 1912.) Trans. Seppo Randell. Helsinki, Finland: Tammi Press.

iv. Edusei, K. (1991). Significant Ghanaian Education: Innovations and Landmarks and Their Socio-Cultural Impact. PhD thesis, Kwame Nkrumah University of Science and Technology, Kumasi, Ghana. pp. 227-229.

v. Eze, E. C. (1998). African Philosophy an Anthology. Massachusetts, USA: Blackwell Publishers Ltd. p.3.

vi. Holl, A. F. C. (2000). Metal and precolonial African society. Walnut Creek, California, USA: Altamira Press. p.3.

vii. Holland, J. (1999). The King Fisher Encyclopedia. London, UK: King Fisher Books. p. 7

viii. Johnson, P and Duberley,J. (2000). Understanding Management Research. Thousand Oaks, CA: Sage Publication. p.64.

ix. Julee, V. (2002). Jewellery making process. Daryaganj, New Delhi, India: New Age International (P) Ltd., Publishers.p.34.

x. Kennett, K. (2013). Arts \& Lifestyle: Jewellery Making with Ordinary Items. Saskatchewan, Canada: Saskatchewan Inc.p.4.

xi. Labi, K. A., and Ansah, J.B. (2008). Kuduo: The Akan Art of Brass Casting. Accra, Ghana: Smart line Publishing Ltd.p.27.

xii. Leedy, P. D. and Ormrod, J.E (2005). Practical Research. Planning and Design, 8th edition. New Jersey, USA: Pearson Prentice Hall Publications.pp.87-90.

xiii. Maryon, H. (1971). Metalwork and Enamelling, 5th edition. New York, USA: Dover Publications Incorporated. p. 21.

xiv. Metropolitan Museum of Art. (2005). African Metalworks. New York, USA: Bryony Reid

xv. Neumann, R.V. (1982). The Design and Creation of Jewellery (3rd ed.). Pennsylvania, USA: Chilton Book Company.p.17.

xvi. Oliver, A. J. (1966). Greek, Roman, and Etruscan Jewelry. The Metropolitan Museum of Art Bulletin. New York, USA.

xvii. Sanders, M., Lewis, P. and Thornhill, A. (2007). Research Methods for Business Students. (4th Ed.). UK: London, Prentice Hall.

xviii. Simmel, G. (1986). Simmel on Culture. London, UK: SAGE Publication. p. 123

xix. Solomon, R. C. and Higgins, K. M. (2010). The Big Questions: A short Introduction to Philosophy. 8th Ed. Wadsworth, USA: Pre-Press PMG.

xx. Summatavet, K. (2005). Folk Tradition and Artistic Inspiration - A Woman's Life in Traditional Estonian Jewelry and Crafts as Told by Anne and Roosi. (Doctoral dissertation, Helsinki: University of Art and Design, Helsinki. Tallinna: Tallinna Raamatutrükikoda).

xxi. Tettey, E. (2012). A Journey through Careers in Manufacturing, Technical \& Vocational Skills. Kumasi, Ghana: Pathfinders Educational Trust.p. 6.

xxii. 22] Tetteh, N. A. and Adu-Agyem, J. (2014). Symbolic and Aesthetical Implications of Precious Metals in Ghana: The Perspective of Akan Culture. International Journal of Innovative Research \& Development. Vol 3 Issue 2.pp. 49-55.

xxiii. 23] Tetteh, N. A. (2017). Unearthing the Potential of Jewellery Fabrication: The case of Wa Municipality. PhD thesis, Kwame Nkrumah University of Science and Technology, Kumasi, Ghana. pp. 56-57.

xxiv. 24] Untracht, O. (1985). Jewellery Concepts and Technology. New York, USA: Doubleday. pp. 2-4. 